DOI: $10.33310 / 2518-7813-2019-65-2-40-46$

УдК 37.014

\author{
Valeriy BUDAK \\ Doctor of Engineering, Professor, Academician of the National Academy of Pedagogical Sciences of Ukraine, \\ Rector of Mykolaiv V.O. Sukhomlynsky National University, Mykolaiv, Ukraine \\ e-mail: office@mdu.edu.ua
}

Oksana OLEKSIUK

PhD in Pedagogy, Assistant Professor, Reader of Pedagogy and Inclusive Education Chair of Mykolaiv V.O. Sukhomlynsky National University, Mykolaiv, Ukraine

e-mail: oleksjukoksana@ukr.net

\title{
CONTEMPORARY METHODOLOGICAL APPROACHES TO THE PROCESS OF FORMING A PERSONALITY OF LEADER-PATRIOT IN THE UNIVERSITY EDUCATIONAL ENVIRONMENT
}

\begin{abstract}
The article arises the issue of forming a personality of a student as a leader-patriot in the University educational environment. It presents the theoretical analysis of the concept «approach» and opens the content of its basic components. The article reveals methodological approaches used by scholars in pedagogical researches on different scientific problems. There is the analysis of the presence of methodological approaches in different models of patriotic, national-patriotic and military-patriotic education of the youth. On the basis of the conducted analysis there have been defined basic methodological approaches that will be used in forming the qualities of a leader-patriot among students in the University educational environment.

Key words: methodology, approach, forming a personality, a leader-patriot, model, patriotic education, military-patriotic education.
\end{abstract}

Since it is up to Universities to fulfil the task of supplement Ukrainian elite with graduates-specialists, a great deal of institutions of the contemporary Ukrainian society must be concerned about continual improvement of the system of national education and upbringing. Study at a University should have not only educational orientation, but a compulsory instructional dimension. Educational-instructional process is aimed at forming among students a high culture, humanistic and democratic world outlook, high moral principles, educating them as citizens-patriots, intellectuals, creative and persevering specialists [11, c. 348].

Universities must provide training of conscious national intellectual class which will encourage renovation and enrichment of intellectual nation's gene pool; they must also carry out education of spiritual elite, augmentation of cultural potential that will provide high effectiveness of the future specialists' activity. All these factors can be achieved by:

- educating future specialists as authoritative, high educated people, bearers of high general, world perceiving, political, professional, legal, intellectual, social-psychological, emotional, physical and ecological culture;

- creating necessary conditions for free development of a personality, his/her thinking and general culture by involving in various types of creativity (scientific-research, technical, cultural, civil, health-sport, legal, etc);

- enriching esthetic experience of students by their participation in revival of forgotten and creation of new national-cultural traditions of a region, city, educational institution, development of students' creativity;

- forming «I-conception» of a creative human being on the basis of self-education, self-upbringing, selfimprovement, moral maturity;

- propaganda of healthy life style, prevention of students' alcohol and drugs addiction, eliminating their vicious habits [11, c. 351].

Besides, «what we lack most of all is professional, patriotic and consolidated national elite that forms political power» [4, c. 179].

Taking all this into consideration, special attention must be paid to forming patriotic personality, in particular such personality that would combine the qualities of a patriot and a leader, which, unfortunately, the contemporary elite of our country lack.

Appearance of new educational tasks requires the search of appropriate ways and steps for solving them. Formation of new methodology, that corresponds to contemporary scientific tasks, should be grounded on awareness of the essence of the process of its development, reasons for changes, defining the tendency of development. Methodology of pedagogics is viewed as a system of knowledge about the structure of pedagogical theory, principles of approach and ways of acquiring knowledge that reflect pedagogical reality as well as the system of activity with acquisition of such knowledge and programs, logics, methods and assessment of the quality of research work. S.U. Honcharenko notices that methodology of pedagogical science is based on the concepts of learning 
the structure and functions of a special form of spiritual assimilation of the results of knowledge; on primary positions that have general scientific sense; logics and methods of pedagogical researches; ways of using the acquired knowledge for improvement of practice. Methodology of education is based on the following principles: 1) objectiveness: adequacy of research approaches and ways for achieving real results, demonstrability, argumentation and logics of research and conclusions; 2) essential analysis: correlation in phenomena under research the outer, special, penetrating into their inner structure, opening the laws of their implementation and functioning, conditions and factors of their development, possibilities of their purposeful change; 3) genetic argumentation: investigation a fact or a phenomenon basing on the analysis of its nature, conditions of its origin, development, fining out qualitative changes (changing one level of functioning into a different one), ascertainment of genetic and social preconditions of appearance of a human's individual peculiarities in the process of postnatal ontogenesis; 4) unity of the logical and historical: combining the study of history of the object and theory, perspectives of its development; 5) conceptual unity of the research: the unity of the defined that is considered the right one and the non-defined, changeable; an integral approach to educational systems: unity in research, careful approach to special studies of separate elements of educational process [6, c. 499].

Methodology as an instrument of perception and transformation of surrounding reality defines the basics directions of pedagogical research, provides its objectiveness, effectiveness, unity, system and results. Methodology of research defines its strategy and to a certain degree stipulates the quality of the acquired results and credibility of the conclusions made. Grounded and realized methodology allows a researcher to acquire a new quality of scientific knowledge.

Methodological principles of a scientific development, pedagogical science in particular, are reflected in the works of N.Huziy, V.Slastionin, S. Palchevsky (axiological aspect), K. Abulhanova-Slavska, O.Bodaliova, V.Hryniova (akmeological aspect), V. Afanasiev, Ye.Yudin, G. Schedrovytsky (systematic approach), N. Bibik, I. Zymnia, L.Horunzhoy, V. Bondarenko (activity approach).

Methodological approach is a tool for realizing methodological grounds of scientific analysis of pedagogical phenomena and processes. In developing the methodology of research of any phenomenon it is principally important to define methodological requirements (i.e. principles) and methodological approaches - aggregation of «interconnected ideas» that trace a line for «reference points» of the investi- gation of the phenomenon under study. Scientific approach is a special way of thinking and perceiving an objective reality that is formed by the conditions of the research, high level of knowledge and professional training and purpose direction. The essence of the definition «approach» in the Ukrainian thesaurus is presented as a complex of ways of regarding something, influence on somebody or something, attitude to somebody or something [2; 8; 12].

Some researchers define methodological approach as a general scientific category where there differentiated the following terms: principle; point of reference; basic conception or belief that makes a basis of research intention according to which the study of the object of research is carried out. Analysis of scientific sources shows that quite frequently researchers (for instance, L.Kravchenko) use the concept «methodological-theoretical approach» or construct «theoretical-methodological principles» (for instance, R.Prima) in the sense of integrated philosophical-social way of conceptualizing a scientific problem which creates a certain framework of its methodological, theoretical and technological aspects, allows to work out a conception which contributes to broadening scientific imaginations about the object of the research, also the model of implementation of the acquired results into practice [9] .

Such understanding of the methodological approach makes it possible to characterize this concept as an assembly of ideas that define general scientific researcher's outlook, principles that make the basis of the strategy of research activity as well as ways, procedures which provide the realization of the chosen strategy in practice [7].

Opportunely, we should point out that the results of the researches of methodological approaches to broadening scientific knowledge in the sphere of professional education (O.Dubaseniuk, N.Yaksa) contributed to their active usage in fundamental researches of contemporary scholars. It is about the expediency of differentiation of the whole amount of methodological approaches into general scientific (which comprise, except for basic ones, such as systematic, activity synergetic) and scientific which are marked as axiological, competence, acmeological approaches.

In the contemporary pedagogical science we can find a great deal of methodological approaches which present different direction of researches and reflect specifics of a particular scientific-research activity in pedagogics.

Most frequently the activity of an educationalist is based on several, not one approach. It is clear that orientations, chosen by the educationalist, must not except each other, but complement. Together they make a strategy of an educational activity and condition the choice of tactics of actions in a particular 
situation and in a certain period of time. It must be emphasized that of all the range of approaches used in a pedagogical activity one orientation is primary (dominating). This orientation forms the peculiarity of an educationalist's individuality in organizing educational work.

Most scholars claim that the approach is a complex pedagogical means and it comprises three basic components:

1) basic notions used in the process of studying, managing and transmitting an educational practice;

2) principles as primary provisions or the main rules of carrying our educational activity;

3) technological as it consists of techniques and methods used in educational work which are chosen in accordance to one or another orientation.

Taking into consideration the estimations mentioned above, let us characterize basic scientific approaches in which we can trace methodological reference points of our scientific research - forming a personality of leader-patriot in the University educational environment.

Thus, T.S. Troyitska marks, «Conceptual perception of national upbringing on the contemporary stage of the development of Ukraine should enrich pedagogical education with theoretical arguments of anthropological, ethno methodological, culturological, axiological approaches, complete the theory of humanization and humanitarian education with anthropological conceptions which overcome the present in scientific works one-sided views regarding humanism, human's nature, cross-culture, diaologics, tolerance, etc and accomplish technologies, models, approaches and methods of knowledge transfer, anthropological expertise of all events taking place at higher educational establishments» [15, c. 70$]$.

Analyzing researches of scholars regarding the use of scientific approaches to studying different pedagogical phenomena, we ought to pay attention to the articles and monographies of O.Dubasenyuk in which the author gives a list of the available scientific approaches. In particular, in her monography «Professional pedagogical education: competence approach» [5, c. 11-18] she offers a great review consisting of twenty six methodological approaches, namely:

- acme-aimed, developing, strategically oriented approach orients pedagogical process to acmeological (creative, self-actualizing, self-realizing) quality of personal and professional attitude of a person, i.e. to achieving high points in the process of all-round development of a personality;

- professionaligraphical approach orients participants of pedagogical process to the result of realiz- ing a certain complex of demands to their future professional activity;

- task-situation approach presupposes realizing pedagogical goals through using educational and upbringing tasks, situations - certain problem situations which require timely solutions which, in its turn, becomes a developing mechanism in formation of a person's three aspects - personality, specialist, citizen;

- technological approach orients pedagogical process to technological organization which to a certain degree severely regiments its main aspects and stages according to technological constitution of educational process;

- $\quad$ reflexive approach directs educational process to creating pedagogical situations which activate reflection (self-consciousness, I-conception) of the participants of educational process;

- eventful approach - using in pedagogical research the principle of time (line development of events in time) that presupposes the analysis of quantity and quality of events of a person in a certain period of time, their interference;

- historically-logical approach allows to analyze pedagogical problems in the context of their genesis, contemporary condition, regularity and tendencies, etc;

- co-evolutional-noospherec approach - considering in the process of a person's development various evolutional background factors (family, group, state, socio cultural, socio natural, space planetarium) which must be combined, unity, correspond each other with the purpose of creating the effect of mutual strengthening;

- stimulus-informational-resourceful approach orients pedagogical process to creating a lot of informational educational environment which stimulates (opens, develops) inner developing resources of the subjects of educational process;

- natural-differential approach orients pedagogical systems to natural principles of organizing their structure, functions, energetic-informational exchange with surrounding environment and to individual characteristics of the subjects of educational activity;

- dialogical approach orients to conceptual thinking concerning the fact that thinking of a personality in the process of formation must turn to virtual dialogical communication with previous forms of culture, as well as with representatives of different generations which interrelate in the common time period when the process of communication of all the participants of educational process becomes free;

- ambivalent approach in pedagogics appeared as a result of meeting polar phenomena of pedagogical practice (collective and individualism, chaos and order, freedom and responsibility, differentiation and integration, etc) and philosophical-psycho- 
logical concept «ambivalence» as a person's ability to comprehend any phenomenon through dual opposition - from two opposite sides which contradict one another and mutually exclude one another which allows to achieve integral status of thinking through mutual change, completion of oppositions, their interpenetration, constant «digestion» of the sense through every opposite pole (S.U. Honcharenko);

- critically-constructive approach realized the possibility of critical approach (interaction) to traditional scientific stereotypes that have appeared in the contemporary pedagogical science, which in its turn presupposes the process of designing - transformation of pedagogical reality or even creation of something new in its frames;

- activity-praxeological, subject-activity, context approach (that manifests activity, subject and context components) in accordance to which the realization of the educational goal is achieved through educational activity of its subjects regarding perception of knowledge, skills and abilities of a certain profession;

- personally-oriented, subject-subject approach is aimed, on the one hand, orientation of educational process to the general goal - development of a personality, on the other hand, - the way of realizing this goal - subject-subject (reciprocal, harmonious) interaction of all the participants of educational process;

- participant-interactive approach (from English «participate») is grounded on the theory of participation. This approach orients participants of educational process to their activity, understanding of complementarity of their skills and personal resources, mutual character of educational process, active communication, self-organization and selfmanagement;

- subjective approach is aimed at orientation of pedagogical process to confirmation of subject orientation (interaction) of its participants. It is known that in objective orientation a person's life activity is determined mostly by outer situations as their objects. The source of life activity in such an approach is situated out of it;

- the narrative approach (from English «narration») is used in psychological, philosophical, historical and pedagogical research through the use of detailed narrative as a way of understanding and reflecting historical phenomena. This approach reflects the subjective opinion of the narrator about certain events;

- the hermeneutical approach provides the development of educator's work not so much based on his knowledge of the child as on the ability to understand («to read») the internal logical coherence, organization of the child's life phenomena. At the same time, the information about the child is con- sidered by the educator not as the irrevocable material, but as a constantly developing one, being created every time, not reproduced at a time and for all by the given standard (S. V. Honcharenko);

- the philosophical-anthropological approach is based on the reflexive tendency to the analysis of educational reality through the prism of humanological disciplines synergy. It marks the reorientation of the educational paradigm from the knowledge reference points of education to the values of personality in the teaching-educational process;

- the fundamental approach involves the orientation of the educational process on the fundamental knowledge, values and universal ways of activity. This approach means the creation of the educational system aimed at the development of invariant, methodologically important, long-lived attainments; the transition from «education for the whole life» to «education through the whole life»;

- the system-synergetic approach allows to reveal the components, system-forming and functional connections of educational systems, processes and to analyze the ability of educational process participants to self-organization, to active creative construction of one's multiple activity; the synergetic methodology assumes the consideration of integrity of identity structure of subjects of teaching-educational process subjects as a set of stable features and variable situations of personal and professional development;

- the integrative approach provides the implementation in the educational process the principle of integrity of knowledge (including the sphere of their interdisciplinarity), educational systems, educational purposes, etc;

- the civilizational-environmental approach requires the conditions of character and organization of the environment (social, educational, group, informative, etc.) in order to effectively and optimally provide the influence of its factors on the formation of the educatee's personality;

- the standardized-axiological approach considers the educational process from the point of view of its compliance with certain standardized society criteria, the peculiarities of its social order and is defined by the necessity to realize the whole system of relations «man-society-nature» for the reflection of its main characteristics on the process of educational tasks implementation;

- cultural approach is determined by the synergy of methodological techniques that provide the analysis of any social and psychological life sphere, including education and pedagogy through the prism of system-forming cultural concepts («culture», «cultural patterns», «standards», «values», «household activities», «lifestyle», «cultural activities», «multiculturalism», «transculturalism», «interculturalism», etc.) 
Attention should be paid to the research of O. M. Trifonova [14], who proposes to consider the following methodological approaches to the organization of educational work as the most applied:

- acmeological (the value of teaching);

- the approach of activity (organization of personal activity);

- personal (the definition of personality as a product of social development, moral and intellectual freedom, the bearer of the right to respect and culture);

- competence-based (acquisition of not only knowledge, abilities and skills, but also of emotionalvalue attitude to the environment experience) has operational-technological, cognitive, motivational, axiological and reflexive components;

- system-defined (relatively independent components are not considered in isolation, but in interrelation of system elements);

- synergetic (co-operative), which leads to changes that ensure the emergence of a new quality;

- structural-historical (the search for not only the problems of theory to explain the phenomena of the world, but also the evolution of methods and ways to achieve results);

- resource (the search and development of potential opportunities of the subject of education, impact analysis of education results);

- modular (the search for principles and regularity of the model development in the aspect of the subjects of education mastering competence system and the system of norms that will help the personality to develop and fulfill oneself in life).

The pedagogical research of N. I. Melnik [10] is also worth attention, in which the scientist proposes to apply separate methodological approaches at each stage of scientific research:

- the first stage is methodologically predictive: dialectical, system-integrated, system-historical, synergetic, interval, thesaurus, acmeological approaches;

- the second stage is socio-pedagogical: cultural, axiological, paradigmatic approaches;

- the third stage is productive: comparative, hermeneutical, parametric, narrative approaches.

The following conclusion of the scientists should be underlined: despite the existence of a wide range of scientifically based methodological approaches, it is legitimate to talk about their complementarity, because each of them has certain limitations, and therefore can not be considered universal. The methodology determines the vector of scientific interpretation by the researcher of the «studied material»; since there are General scientific and specifically scientific methodologies defined [13, p. 127].
Before referring to the characterization of a certain methodological approach content, it is necessary to find out what content is considered more appropriate for the concept of «approach» considering the purpose of initiate scientific research. It should be mentioned that we agree with the opinion of those researchers who confirm that choosing their own scientific approach, it would make sense to describe in detail the theoretical model of «some objective reality», the deepening of the scientific understanding of which gives a «corresponding result» [3].

Carrying out the scientific research in the field of military-patriotic education of students in the educational space of the University, the analysis of various models of patriotic, national-patriotic and militarypatriotic education of youth has been conducted [1, p. 89-95] in order to identify the common and the different in this process and the possibility of applying the received conclusion in the formation of the leaderpatriot personality among students. We arrived at a conclusion that only five of the nine presented models reflect methodological approaches (see table 1).

The greatest number of applied research approaches were eight, the fewest - three approaches. It is quite clear that each of the scientists chooses those methodological/conceptual approaches that are most clearly expressed in his research of the scientific problem.

Taking into consideration that the activity and personality-activity approaches can be regarded close in meaning and such that consider the activity aspect, we can make a conclusion that there is an activity approach in all the models considered. In more than $60 \%$ of the analyzed models there were announced axiological and environmental approaches. Almost in $40 \%$ of the models systemic, personality-oriented, humanistic and culturological approaches are offered in scientific research. And only in $20 \%$ of the analyzed models such methodological approaches as: epistemological, axiological, hermeneutic, socialization, academic, competence and ambivalent were mentioned.

Thus, methodological approaches to the research of the problem of forming the qualities of a leaderpatriot among students at various stages of the research can be defined as follows: professional-personal, systemic, acmeological, axiological, ambivalent, participative-interactive, activity-based, personality-oriented, environmental and competence approaches.

Prospects for further research are associated with the development of the program and description of the model of forming the qualities of leader-patriot among students as a component of military-patriotic education in the University educational environment. 
Table 1 - Comparison of methodological approaches occurrence in the models of patriotic, nationalpatriotic and military-patriotic education of youth

\begin{tabular}{|c|c|c|c|c|c|c|c|c|c|c|c|c|c|c|c|}
\hline $\begin{array}{r}\text { Name of scientific } \\
\text { approach }\end{array}$ & 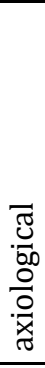 & 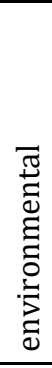 & 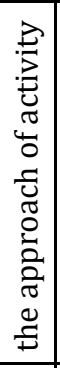 & 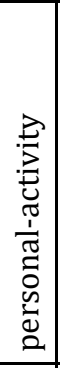 & 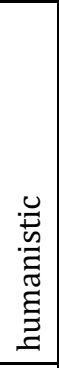 & 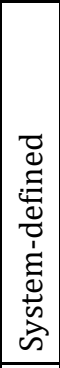 & 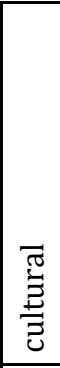 & 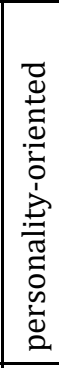 & 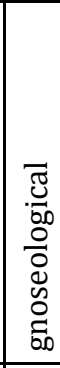 & 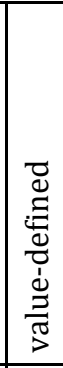 & 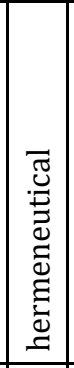 & 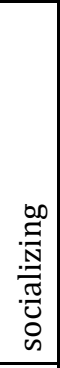 & 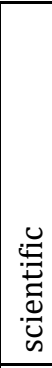 & 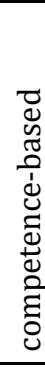 & $\begin{array}{l}\frac{\overrightarrow{0}}{0} \\
\frac{\pi}{\pi} \\
\text { है } \\
\text { है }\end{array}$ \\
\hline $\begin{array}{l}\text { Model of patriotic education of students } \\
\text { in the pedagogical University educational }\end{array}$ & $\mathrm{X}$ & $\mathrm{X}$ & $\mathrm{X}$ & & $\mathrm{X}$ & $\mathrm{X}$ & & & $\mathrm{X}$ & $\mathrm{X}$ & $\mathrm{X}$ & & & & \\
\hline Model of patriotic education organization in higher & $\mathrm{X}$ & $\mathrm{X}$ & $\mathrm{X}$ & & & $\mathrm{X}$ & $\mathrm{X}$ & $\mathrm{X}$ & & & & & & $\mathrm{X}$ & \\
\hline $\begin{array}{l}\text { Structural and functional model of patriotic educa- } \\
\text { tion of high school students in the process of tourism }\end{array}$ & $\mathrm{X}$ & & & $\mathrm{X}$ & $\mathrm{X}$ & & $\mathrm{X}$ & & & & & $\mathrm{X}$ & & & \\
\hline $\begin{array}{l}\text { Model of patriotic education of students-future } \\
\text { teachers of geography by means of tourist }\end{array}$ & & & $\mathrm{X}$ & & & & & $\mathrm{X}$ & & & & & $\mathrm{X}$ & & \\
\hline $\begin{array}{l}\text { Model of military-patriotic training of reserve } \\
\text { officers in civilian higher educational institutions }\end{array}$ & & $\mathrm{X}$ & & $\mathrm{X}$ & & & & & & & & & & & $\mathrm{X}$ \\
\hline number of choices & 3 & 3 & 3 & 2 & 2 & 2 & 2 & 2 & 1 & 1 & 1 & 1 & 1 & 1 & 1 \\
\hline
\end{tabular}

\section{References}

1. Budak V.D. Model viiskovo-patriotychnoho vykhovannia studentskoi molodi: teoretychnyi aspekt / Zbirnyk naukovykh prats «Pedahohichni nauky» № 80 tom 2. KhDU. 2017. 256 s. S. 89-95

2. Vitvytska S. S. Osnovy pedahohiky vyshchoi shkoly : pidruch. za modulno-reitynhovoiu systemoiu navchannia dlia stud. mahistr. / S. S. Vitvytska. - K.: Tsentr navchalnoi literatury, 2006. - $401 \mathrm{s.}$

3. Honcharenko S.U. Pedahohichni zakony, zakonomirnosti, pryntsypy : suchasne tlumachennia / Semen Ustymovych Honcharenko. - Rivne : Volynski oberehy, 2012. - $192 \mathrm{~s}$.

4. Hordiienko M. Evoliutsiia natsionalnoi derzhavy v umovakh novoho svitoporiadku // Ukrainoznavchyi almanakh. Vyp. 1: Ukrainskyi obraz svitu: osoblyvist u svitovomu konteksti. K., 2009. S. 174-180.

5. Dubaseniuk 0.A., Vozniuk O.V. Profesiina pedahohichna osvita: kompetentnisnyi pidkhid: monohrafiia / za red. 0. A. Dubaseniuk. - Zhytomyr : Vyd-vo ZhDU im. I. Franka, 2011. - S. 11-18.

6. Entsyklopediia osvity / APN Ukrainy ; [holov. red. V. H. Kremen]. - K. : Yurinkom Inter, 2008. - $1040 \mathrm{~s}$

7. Zhyhir V. I. Metodolohichni pidkhody yak osnova naukovo-pedahohichnykh doslidzhen u profesiinii osviti / V. I. Zhyhir // Pedahohika formuvannia tvorchoi osobystosti u vyshchii i zahalnoosvitnii shkolakh. - 2016. - Vyp. 48. - S. 107-115. - Rezhym dostupu: http://nbuv.gov.ua/UJRN/Pfto_2016_48_16.

8. Ziaziun I. A. Filosofiia postupu i prohnozu osvitnoi systemy [tekst] // Pedahohichna maisternist: problemy, poshuky, perspektyvy: [monohrafiia] / I. A. Ziaziun. - K.; Hlukhiv : RVV HDPU, 2005. - S. 10-18.

9. Kravchenko L.M. Neperervna pedahohichna pidhotovka menedzhera osvity: monohrafiia. Poltava: Tekhservis, $2006.420 \mathrm{~s}$.

10. Melnyk N. I. Kontseptsiia doslidzhennia profesiinoi pidhotovky doshkilnykh pedahohiv u krainakh Zakhidnoi Yevropy: stratehichnyi aspekt / N. I. Melnyk // Molodyi vchenyi. - 2016. - № 11. - S. 454-459. - Rezhym dostupu: http://nbuv.gov.ua/ UJRN/molv_2016_11_108.

11. Pedahohika vyshchoi shkoly: navch. posib. / Z. N. Kurliand, R. I. Khmeliuk, A. V. Semenova ta in.; za red. Z. N. Kurliand. 3-tie vyd., pererob. i dop. K.: Znannia, 2007. 495 s.

12. Skalenko O. Hlobalni rezervy postupu. - K.: Osnovy, 2000. - $394 \mathrm{~s}$.

13. Slovnyk-dovidnyk z profesiinoi pedahohiky. Za red. A. Semenovoi. Odesa. Palmira. 2006. $272 \mathrm{~s}$.

14. Tryfonova 0.M. Pro naukovo-pedahohichni pidkhody u doslidzhenniakh / O.M.Tryfonova // Naukovi zapysky. - Seriia: pedahohichni nauky. - Kirovohrad: RVV KDPU im. V. Vynnychenka, 2015. - Vyp.135. - S.206-211.

15. Troitska T. Antropolohichni zasady sotsializatsii studentskoi molodi v polikulturnomu suspilstvi: problemy, kolizii, retseptsii // Polikulturnist, dialoh i zlahoda: ukrainski realii: materialy Mizhnarodnoi naukovo-praktychnoi konferentsii (22-23 travnia 2008 r.). Melitopol: TOV «Vydavnychyi budynok MMD», 2008. 304 s. S. 68-70. 
Валерий Будак, Оксана Олексюк. Современные методологические подходы к процессу формирования личности лидера-патриоты в образовательном пространстве университета

В статье затрагивается вопрос формирования в образовательном пространстве университета личности студента как лидера-патриота. Подан теоретический анализ понятия «подход», раскрыто содержание его основных компонентов. Приведены методологические подходы, которые используются учеными в педагогических исследованиях из разных научных проблем. Осуществлен анализ наличия методологических подходов в разных моделях патриотического, национально-патриотического и военнопатриотического воспитания молодежи. На основе проведенного анализа определены основные методологические подходы, которые будут применены при формировании в образовательном пространстве университета качеств лидера-патриота у студенческой молодежи.

Ключевые слова: методология. подход, формирование личности, лидер-патриот, модель, патриотическое воспитание, военно-патриотическое воспитание.

Валерій Будак, Оксана Олексюк. Сучасні методологічні підходи до процесу формування особистості лідера-патріота в освітньому просторі університету

Навчально-виховний процес покликаний формувати в студентів високу культуру, гуманістичний $i$ демократичний світогляд, високі моральні якості, виховувати їх громадянами - патріотами, інтелігентами, творчими й цілеспрямованими спеціалістами.

3 огляду на це особливої уваги потребує розв'язання завдання формування патріотично налаштованої особистості, окрема такої, яка б поєднувала якості та риси патріота та лідера, яких, на жаль, дуже бракує серед сучасної еліти нашої країни.

Інструментом реалізації методологічних підстав наукового аналізу педагогічних явищ і процесів $\epsilon$ методологічний підхід. У сучасній педагогічній науці існує велика кількість методологічних підходів, які представляють різні напрямки досліджень і відображають специфіку конкретної науково-дослідної діяльності в галузі педагогіки.

Здійснюючи наукові дослідження у напрямку військово-патріотичного виховання студентської молоді в освітньому просторі університету був проведений аналіз різних моделей патріотичного, національно-патріотичного та військово-патріотичного виховання молоді. Найбільша кількість застосованих у дослідженні підходів налічувала вісім, найменша кількість - три підходи. Цілком зрозуміло, що кожен із науковців обирає ті методологічні/концептуальні підходи, які найбільш ярко виражені саме в його дослідженні наукової проблеми.

Отже, методологічними підходами до дослідження проблеми формування якостей лідера-патріота серед студентської молоді на різних етапах дослідження можуть бути визначені наступні: професійноособистісний, системний, акмеологічний, аксіологічний, амбівалентний, партисипативно-інтерактивний, діяльнісний, особистісно-орієнтований, середовищний і компетентісний підходи.

Перспективи подальших досліджень пов'язані з розробкою програми та опису моделі формування якостей лідера-патріота серед студентської молоді як складової військово-патріотичного виховання в освітньому просторі університету.

Ключові слова: методологія. підхід, формування особистості, лідер-патріот, модель, патріотичне виховання, військово-патріотичне виховання. 